\title{
Measurement indicators and an evaluation approach for assessing urban sustainable development: A case study for China's Jining City
}

\author{
Feng $\mathrm{Li}^{\mathrm{a}}$, Xusheng Liu ${ }^{\mathrm{b}}$, Dan $\mathrm{Hu}^{\mathrm{a}}{ }^{\mathrm{a} *}$, Rusong Wang ${ }^{\mathrm{a}}$, Wenrui Yang ${ }^{\mathrm{a}}$, Dong $\mathrm{Li}^{\mathrm{a}}$, Dan Zhao ${ }^{\mathrm{a}}$ \\ a State Key Laboratory of Urban and Regional Ecology, Research Center for Eco-Environmental Sciences, Chinese Academy of Sciences, Shuangqing Road 18, \\ Haidian District, Beijing 100085, China \\ ${ }^{\mathrm{b}}$ Chinese Academy of Forest Inventory and Planning, State Forestry Administration, Hepingli East Street 18, Xicheng District, Beijing 100714, China
}

\section{A R T I C L E I N F O}

\section{Article history:}

Received 8 October 2007

Received in revised form 25 October 2008

Accepted 27 October 2008

Available online 20 December 2008

\section{Keywords}

Urban ecosystem

Urban evaluation indicators

Ecosystem services

Sustainable development

\begin{abstract}
A B S T R A C T
Cities are complex ecosystems affected by social, economic, environmental, and cultural factors. The problem of attaining urban sustainable development is thus an important challenge. The development of evaluation indicators and a method for assessing the status of urban sustainable development will be required to support urban ecological planning, construction, and management. By using Jining City in China's Shandong Province as a case study, the authors developed a system of 52 indicators of urban sustainable development that address economic growth and efficiency, ecological and infrastructural construction, environmental protection, social and welfare progress. The authors developed a Full Permutation Polygon Synthetic Indicator method to evaluate the capacity for urban sustainable development at different times during the next two decades. The results of our research indicate that the value of a synthetic indicator for sustainable development of Jining City was 0.24 in 2004, which indicates a low level of sustainable development. According to the ecological planning of Jining City (2004-2020), the indicator will improve to 0.45 in 2007 and 0.62 in 2010, indicating significant improvements in sustainable development, and will reach 0.90 in 2020, indicating excellent potential for sustainable development. The Full Permutation Polygon Synthetic Indicator method provides a comprehensive, intuitive approach that reflects the system integration principle that the whole can be more than the sum of its parts. The approach thus provides a promising basis for decision-making to support urban sustainable development and monitoring of the effectiveness of these decisions.
\end{abstract}

(C) 2008 Elsevier B.V. All rights reserved.

\section{Introduction}

The world is becoming an increasingly urban place. About $65 \%$ of the world's population is expected to live in urban areas by the year 2025 (Schell and Ulijaszek, 1999). Due to the rapid pace of urbanization, natural ecosystems are increasingly replaced by cities (Pauleit and Duhme, 2000; Attwell, 2000; Pauleit et al., 2005; Fang et al., 2005). Urbanization promotes rapid social and economic development, but at the same time, leads to many problems, such as concentration of the population, traffic jams, housing shortages, resource shortages, biodiversity reductions, "heat island" effects, noise, and air and water pollution (Savard et al., 2000; Herzele and Wiedemann, 2003; Wang et al., 2004; Li et al., 2005a,b). People are increasingly realizing the importance of a sustainable urban envi-

\footnotetext{
* Corresponding author. Tel.: +86 10 62849103/9199; fax: +86 1062849103 . E-mail addresses: lifeng@rcees.ac.cn (F. Li), liuxush@163.com (X. Liu), hudan@rcees.ac.cn (D. Hu), wangrs@rcees.ac.cn (R. Wang), oydragon@126.com (W. Yang), uriel_li@yahoo.com.cn (D. Li).
}

ronment that will mitigate or eliminate these problems (Shearer et al., 2006; Jenny and Ericson, 2006), and many countries have already enacted strategies to promote urban sustainable development (Costanza et al., 1997; Bolund and Hunhammar, 1999; Diamantini and Zanon, 2000).

China is experiencing particularly fast urbanization and industrialization, accompanied by a rapidly increasing gross domestic product (GDP), rapidly expanding urban infrastructures, and dramatic changes in the quality of life in cities. Establishing an efficient, healthy, and civilized urban society, including livable human settlements and regional ecological security, has become a priority for governments and institutions around the world, and is increasingly becoming a national priority in China too. The Chinese government has already begun to propose people-oriented development strategies for constructing sustainable and harmonious cities (Wang and $\mathrm{Xu}, 2005$; Cheng et al., 2006).

Cities are complex systems affected by diverse social, economic and environmental factors, with many conflicts and interactions among these factors (Ma and Wang, 1984). Simultaneously, cities are sources of global environmental pollution and ecological 
damage, and serve as major sinks for materials, energy, information, capital, and population. In the broader sense, sustainable development means the capacity to meet the needs of the present without compromising the ability of future generations to meet their own needs. Urban sustainable development does not mean the sustainable development of any single economic, social, or environmental subsystem, nor simply adding to the sustainability of these subsystems. Instead, it attempts to balance economic growth, ecological construction, environmental protection, and social progress, and the difficulty of this challenge has made it a major focus of current research around the world (Riley, 2001; Button, 2002; Repetti and Desthieux, 2006).

The concept of sustainable development was formulated in response to a growing awareness that there are several important relationships between processes such as social and economic development, global, regional and local environmental problems, increase in population and urban built-up area (Malkina-Pykh, 2002). Urban planning, especially land use planning and management are in constant mutation throughout the world. With sustainability as the goal, the use of indicators for urban monitoring and regulation is becoming more and more in demand (Repetti and Desthieux, 2006). Zhang et al. (2003) did many research works about assessment on eco-city and put forward a set of indicator system. The workshops of the Lebanese Environment and Development Observatory (LEDO) at the Ministry of Environment (MoE) concluded with 110 indicators related to demography, standard of living and consumption, production patterns, agriculture, industry, energy, services, transport, air, water, land and soil, biodiversity, activities actors, policies and strategies (Nader et al., 2008). An indicator is an empirical and indirect interpretation of reality, and being used more and more frequently in the assessment of urban ecosystem, sustainability, and management of cities, land use, and the environment (OECD, 1997; Merkle and Kaupenjohann, 2000). The purpose of indicators is to provide a tool for guidance in sustainability policies, including monitoring of measures and their results, and communication to the public (Spangenberg et al., 2002). It promotes a better understanding of complex phenomena and provides a common reference to different stakeholders with various preoccupations (Repetti and Desthieux, 2006). But their implementation within institutions remains difficult and a large number of challenges exist in creating an indicator system of urban sustainable development that is relevant to the needs of its users (OECD, 1997; Merkle and Kaupenjohann, 2000; Repetti and Desthieux, 2006).

In the wake of “Agenda 21", the United Nation's plan for sustainable development (http://www.un.org/esa/sustdev/documents/ agenda21/index.htm), China developed its own program, referred to as "China's Agenda 21" (http://www.acca21.org.cn/ english/index.html), in 1994, to promote development goals that will establish delightful conditions for working and living, provided by a sound urban configuration, a matching infrastructure, and comfortable circumstances. Some Chinese cities have made strong efforts to implement China's Agenda 21 based on research achievements from the different perspectives of economics, environmental sciences, ecology, and geography (Wang et al., 2004; Li et al., 2005a,b). However, assessment indicators and methodologies must be developed to provide objective evidence for evaluating the progress towards urban sustainable development achieved by urban ecological planning, construction, and management. Research on such assessment methods is currently in its early phases, with most studies focusing on specific aspects rather than a synthetic set of indicators or methodologies that evaluate a wider range of factors and integrate their interactions (Haughton, 1997; Huang et al., 1998; Landelma et al., 2000; Holden, 2006; de Groot, 2006; Zhang et al., 2006).
In a word, people already realized the significance of urban sustainable development and have carried out some research. But there are no effective indicators and evaluation method for urban sustainable development. This paper aims to develop a more comprehensive set of indicators and put forward a new evaluation method for urban sustainable development, and the authors illustrate how these indicators and methods can be used through a case study for Jining City in China's Shandong Province. It provides a promising basis for decision-making to support urban sustainable development and monitoring of the effectiveness of these decisions.

\section{Study area}

Jining City lies between longitudes $115^{\circ} 54^{\prime} \mathrm{E}$ and $117^{\circ} 06^{\prime} \mathrm{E}$, and between latitudes $34^{\circ} 25^{\prime} \mathrm{N}$ and $35^{\circ} 55^{\prime} \mathrm{N}$, in the southern part of Shandong Province, a region that connects eastern and northern China. In this paper, Jining City refers to the main urban area plus all surrounding administrative regions governed by the city, including the surrounding rural areas. The city lies between the Shandong Peninsula and China's central plains, between the Yangtze and Huang River. Jining lies near the intersection of four provinces (Shandong, Jiangsu, Henan, and Anhui), and comprises 12 sub-districts, counties, and towns, with a total area of $10,684.9 \mathrm{~km}^{2}$ (Fig. 1). Jining has $7,989,000$ inhabitants, of which $51.3 \%$ are male and $71.4 \%$ are rural-registered citizens. In 2005 , the birth rate was $9.56 \%$ and the death rate was $5.17 \%$ o (Jining Municipal Statistical Bureau, 2005). The local climate is comfortable, as Jining is governed by a temperate continental monsoon climate, with four distinct seasons. The average annual temperature is $13.6^{\circ} \mathrm{C}$, and temperatures range from $-1.7^{\circ} \mathrm{C}$ in January to $26.8^{\circ} \mathrm{C}$ in July, with a frost-free period lasting 199 days. The mean annual precipitation is $707.1 \mathrm{~mm}$, and total precipitation ranges from $441.7 \mathrm{~mm}$ in summer to $27.8 \mathrm{~mm}$ in winter. The average annual duration of sunshine is $2406.8 \mathrm{~h}$ (Jining Municipal Statistical Bureau, 2005).

The urban available water resources total about 4.85 billion $\mathrm{m}^{3}$, composed of 3.11 billion $\mathrm{m}^{3}$ of surface water and 1.74 billion $\mathrm{m}^{3}$ of ground water, amounting to $607 \mathrm{~m}^{3}$ per capita. A total of 91 rivers in this area drain catchments larger than $50 \mathrm{~km}^{2}$, and have a total length of $1516 \mathrm{~km}$. East of Jining lies a mountainous region with hills ranging between 80 and $649 \mathrm{~m}$ above sea level. The western part of the city lies the flood plain of the Huang River, at an elevation of 40-258 $\mathrm{m}$ above sea level. Between the mountains and the flood plain lies a group of lakes: Nanyang Lake, Dushan Lake, Shaoyang Lake, and Weishan Lake. About $47.6 \%$ of Jining City lies in plains, versus $17.3 \%$ for marsh lands, $13.7 \%$ for lakes, and $21.4 \%$ for steep terrain (mountains and hills) (Jining Municipal Statistical Bureau, 2005).

Jining is in the deciduous broad-leaved forest vegetation zone. The eastern part of the area is hilly, and contains planted vegetation such as Pinus tabulaeformis and Quercus acutissima. In contrast, for historical reasons and as a result of thousands of years of human activities, some of the area's natural vegetation has already disappeared. Nonetheless, biodiversity remains high. There are 127 families (containing 904 species) of natural vegetation, more than 30 species of animals, 78 species of fishes, 36 species of mollusks, and 201 species of birds (Jining Municipal Statistical Bureau, 2005).

Jining lies near proven deposits of more than 70 kinds of mineral and other geological products, including large deposits of coal, limestone, gypsum, barite, thulium, phosphorite, ironstone, copper, and vanadium; $3400 \mathrm{~km}^{2}$ (32\% of the total area) are underlain by coal deposits. The area is in dire need of ecological restoration because of widespread environmental pollution and ecological 


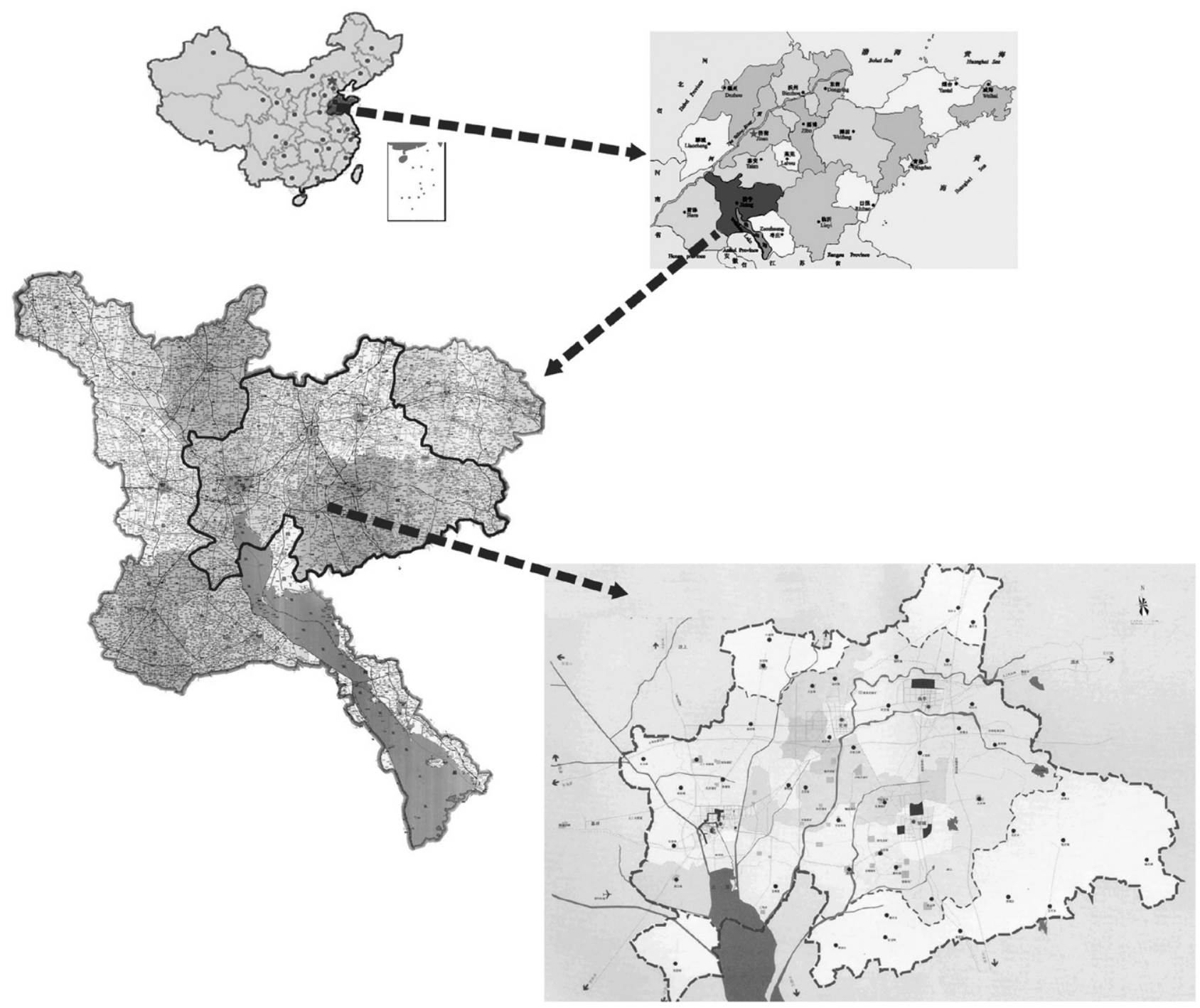

Fig. 1. Location of the study area.

damage induced by mining. The most significant natural disasters that occur in the Jining area are drought (which occurs on average every $4-5$ years), flooding (every 3-4 years).

In 2003, the gross domestic product of Jining reached 88.26 billion RMB (about US\$ 11.4 billion at current exchange rates), which amounts to 11,048 RMB per capita. The agriculture and industry product value accounted, respectively, for $14 \%$ and $49 \%$ of the GDP, the service and other product value accounted for $37 \%$ (Jining Municipal Statistical Bureau, 2005).

Jining has a glorious 6000-year history of civilization and a flourishing culture. The city is the home town for China's famous five sages: Confucius, Mencius, Yancius, Zencius, and Zisicius. The ancient Shizu, Confucian, Great Canal, and "Water Margin" cultures have long histories in this area.

\section{Methodology}

An indicator system for urban sustainable development must embody the state, processes, and strengths of a city's progress and must reflect the current status of the urban economy and environment and of ecological and social construction. The design of such indicators should be subject to the following primary prin- ciples (Button, 2002; Wang and Xu, 2005; Repetti and Desthieux, 2006).

Maturity: The indicator system should embody the social, economic, ecological, environmental, and institutional aspects of the city, with corresponding attention.

Objectivity: The indicator system should objectively reflect the scientific consensus on sustainable development, and especially the social evenness and the needs of the children.

Independence: The meanings of the indicators should be independent to avoid overlap and autocorrelation.

Measurability: Indicators should be measurable; it should be possible to quantify even qualitative indicators using appropriate quantification techniques.

Accessibility: The difficulty of collecting and quantifying the data and indicators must be low enough to permit practical use of the indicator.

Dynamics: Indicators should be sensitive to temporal, spatial, or structural changes in the system to reflect the changes of the social, economic and environmental development.

Relative stability: Indicators should capture long-term rather than short-term processes. However, no indicators should exhibit abso- 
Table 1

Indicator system used to evaluate urban sustainable development in Jining City.

\begin{tabular}{|c|c|c|c|c|c|c|}
\hline \multirow[t]{2}{*}{ Third-level indicator } & \multirow[t]{2}{*}{ Units } & \multirow[t]{2}{*}{ Target value } & \multirow[t]{2}{*}{ Value in 2004} & \multicolumn{3}{|c|}{ Planned future value } \\
\hline & & & & 2007 & 2010 & 2020 \\
\hline (1) Per capita GDP & RMB & $\geq 33,000$ & 13,700 & 18,000 & 25,000 & 55,000 \\
\hline (2) Average annual per capita tax revenues & RMB & $\geq 5,000$ & 674 & 1000 & 2,500 & 5,000 \\
\hline (3) Average annual income per farmer & RMB & $\geq 11,000$ & 3648 & 4000 & 6,000 & 11,000 \\
\hline (4) Average annual income per urban resident & RMB & 24,000 & 10,254 & 10,600 & 13,000 & 24,000 \\
\hline (5) Proportion of GDP generated by the service industry & $\%$ & $\geq 45$ & 34.6 & 40 & 45 & 55 \\
\hline $\begin{array}{l}\text { (6) Energy consumption ( } t \text { coal equivalent) per 10,000 RMB } \\
\text { of GDP }\end{array}$ & $\mathrm{t} / 10^{4} \mathrm{RMB}$ & $\leq 1.4$ & 2.68 & 1.3 & 1.0 & 0.5 \\
\hline (7) Water consumption per 10,000 RMB of GDP & $\mathrm{t} / 10^{4} \mathrm{RMB}$ & $\leq 150$ & 240 & 180 & 150 & 50 \\
\hline $\begin{array}{l}\text { (8) Proportion of all companies that have received } \\
\text { ISO-14000 certification }\end{array}$ & $\%$ & $\geq 20$ & 3.8 & 4.9 & 10 & 20 \\
\hline (9) GDP per unit area covered by the city (GDP density) & $10^{4} \mathrm{RMB} / \mathrm{km}^{2}$ & 5,000 & 826 & 1200 & 2,000 & 5,000 \\
\hline $\begin{array}{l}\text { *(10) Proportion of GDP devoted to environmental } \\
\text { investment }\end{array}$ & $\%$ & 8 & 1.31 & 1.7 & 2.1 & 3.0 \\
\hline (11) Forest coverage & $\%$ & $\geq 19$ & 17 & 23 & 24 & 27 \\
\hline (12) Proportion of the natural reserves & $\%$ & $\geq 17$ & 16.3 & 17.7 & 18 & 20 \\
\hline (13) Proportion of degraded land undergoing restoration & $\%$ & $\geq 90$ & 34.5 & 49.1 & 70 & 100 \\
\hline (14) Per capita area of public urban green space & $\mathrm{m}^{2}$ & $\geq 11$ & 3.54 & 8 & 15 & 20 \\
\hline $\begin{array}{l}\text { (15) Proportion of infrastructure that qualifies as ecological } \\
\text { construction }\end{array}$ & $\%$ & $\geq 80$ & 84 & 86 & 90 & 95 \\
\hline (16) Proportion of green cover in the built-up urban area & $\%$ & $\geq 45$ & 33 & 37.5 & 40 & 45 \\
\hline (17) The proportion of restored mining area & $\%$ & 100 & 34 & 48 & 85 & 100 \\
\hline (18) Proportion of the total area covered by wetlands & $\%$ & 18.2 & 18.2 & 18.2 & 18.2 & 18.2 \\
\hline $\begin{array}{l}\text { (19) Proportion of eco-counties meeting the standard of } \\
\text { SEPA }\end{array}$ & $\%$ & 80 & 0 & 20 & 50 & 80 \\
\hline (20) Proportion of impervious land & $\%$ & 25 & 60 & 50 & 40 & 20 \\
\hline (21) Proportion of rivers with natural bank & $\%$ & 100 & 40 & 50 & 70 & 90 \\
\hline $\begin{array}{l}\text { (22) Proportion of Ecological Impact Assessment done for } \\
\text { projects }\end{array}$ & $\%$ & 100 & 60 & 80 & 90 & 100 \\
\hline $\begin{array}{l}\text { (23) Proportion of people participated in environmental } \\
\text { protection activities. }\end{array}$ & $\%$ & 100 & 60 & 80 & 90 & 100 \\
\hline $\begin{array}{l}\text { (24) Number of days when the urban air quality index } \\
\text { reaching Class II or better }\end{array}$ & Days & $\geq 280$ & 161 & 240 & 280 & 340 \\
\hline $\begin{array}{l}\text { (25) Proportion of water areas in which pollution levels are } \\
\text { below the limit specified in the national standards }\end{array}$ & $\%$ & 100 & 60 & 80 & 90 & 100 \\
\hline (26) $\mathrm{SO}_{2}$ discharge per $10,000 \mathrm{RMB}$ of GDP & $\mathrm{kg} / 10^{4} \mathrm{RMB}$ & $<5.0$ & 16.6 & 8.8 & 7.0 & 5.0 \\
\hline $\begin{array}{l}\text { (27) Chemical oxygen demand (COD) discharged into } \\
\text { surface water per 10,000 RMB of GDP }\end{array}$ & $\mathrm{kg} / 10^{4} \mathrm{RMB}$ & $<5.0$ & 7.3 & 3.7 & 3.5 & 2.5 \\
\hline $\begin{array}{l}\text { (28) Proportion of the urban drinking water supply that is } \\
\text { safe to drink according to the national standards }\end{array}$ & $\%$ & 100 & 100 & 100 & 100 & 100 \\
\hline (29) Proportion of centralized treatment of urban sewage & $\%$ & $\geq 70$ & 33.3 & 65 & 70 & 80 \\
\hline (30) Proportion of industrial water that is recycled & $\%$ & $\geq 50$ & 3.3 & 23 & 50 & 80 \\
\hline $\begin{array}{l}\text { (31) Proportion of the rural sewage discharging that meets } \\
\text { national pollution standards }\end{array}$ & $\%$ & 100 & 10 & 60 & 80 & 100 \\
\hline $\begin{array}{l}\text { (32) Proportion of total hours per year in which noise levels } \\
\text { are below the level specified in the national standard }\end{array}$ & $\%$ & $\geq 95$ & -60 & 80 & 95 & 100 \\
\hline $\begin{array}{l}\text { (33) Proportion of urban domestic wastes that are treated } \\
\text { according to national standards }\end{array}$ & $\%$ & 100 & 34 & 80 & 100 & 100 \\
\hline $\begin{array}{l}\text { (34) Proportion of industrial solid wastes that are treated } \\
\text { and reused }\end{array}$ & $\%$ & $\geq 80$ & 92 & 95 & 95 & 100 \\
\hline $\begin{array}{l}\text { (35) Proportion of tourists who are satisfied with the } \\
\text { environment at tourism sites }\end{array}$ & $\%$ & 100 & 60 & 80 & 90 & 100 \\
\hline (36) Use of inorganic fertilizers per unit area (use intensity) & $\mathrm{kg} / \mathrm{ha}$ & 300 & 884 & 420 & 400 & 300 \\
\hline (37) Proportion of livestock wastes that are treated & $\%$ & 100 & 27 & 100 & 100 & 100 \\
\hline $\begin{array}{l}\text { (38) Proportion of industrial sewage; discharging that } \\
\text { meets national standards }\end{array}$ & $\%$ & 100 & 97 & 100 & 100 & 100 \\
\hline (39) Proportion of the population residing in urban areas & $\%$ & $\geq 55$ & 38 & 50 & 55 & 65 \\
\hline $\begin{array}{l}\text { (40) Proportion of homes and businesses that use natural } \\
\text { gas instead of coal }\end{array}$ & $\%$ & $\geq 92$ & 91 & 96 & 100 & 100 \\
\hline (41) Proportion of urban buildings that are centrally heated & $\%$ & 80 & 32 & 45 & 60 & 80 \\
\hline $\begin{array}{l}\text { (42) Engle's coefficient, proportion of income expended on } \\
\text { food (Wang et al., 2006) }\end{array}$ & $\%$ & $<40$ & 39 & 38 & 35 & 30 \\
\hline $\begin{array}{l}\text { (43) Gini's coefficient, a number between zero and one } \\
\text { that measures the degree of inequality in the } \\
\text { distribution of income in a given society (Kimura, 1994) }\end{array}$ & None & $0.3-0.4$ & 0.32 & 0.31 & 0.3 & 0.3 \\
\hline $\begin{array}{l}\text { (44) Proportion of high school graduates who enter a } \\
\text { university or college }\end{array}$ & $\%$ & $\geq 30$ & 70 & 75 & 80 & 85 \\
\hline $\begin{array}{l}\text { (45) Proportion of the population that is satisfied with } \\
\text { their environment }\end{array}$ & $\%$ & $>90$ & 80 & 90 & 95 & 100 \\
\hline (46) Average number of years of education per citizen & Year & 14 & 6.5 & 8 & 10 & 12 \\
\hline $\begin{array}{l}\text { (47) Number of people who have graduated from at least } \\
\text { technical programs and high school per } 10,000 \text { people }\end{array}$ & per 10,000 people & 600 & 324 & 360 & 420 & 600 \\
\hline
\end{tabular}


Table 1 (Continued)

\begin{tabular}{|c|c|c|c|c|c|c|}
\hline \multirow[t]{2}{*}{ Third-level indicator } & \multirow[t]{2}{*}{ Units } & \multirow[t]{2}{*}{ Target value } & \multirow[t]{2}{*}{ Value in 2004} & \multicolumn{3}{|c|}{ Planned future value } \\
\hline & & & & 2007 & 2010 & 2020 \\
\hline *(48) Average life expectancy & Years & 90 & 74 & 75 & 77 & 80 \\
\hline (49) Road area per person & $\mathrm{m}^{2}$ & 15 & 13 & 20 & 22 & 25 \\
\hline (50) Average living space per person & $\mathrm{m}^{2}$ & 26.6 & 21 & 27 & 30 & 33 \\
\hline (51) Water use for living per person & $\mathrm{m}^{3}$ & 120 & 50 & 70 & 100 & 120 \\
\hline (52) Hospital beds per ten thousand population & Bed & 45 & 23 & 30 & 35 & 40 \\
\hline
\end{tabular}

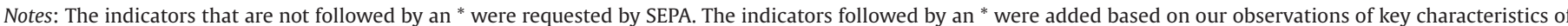

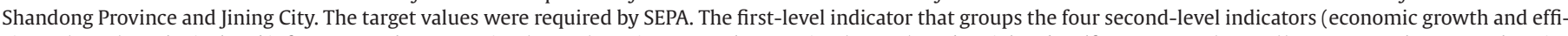

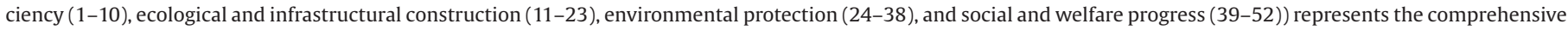
capacity for urban sustainable development.

lute invariability, since the whole indicator system must respond to changes over time.

\subsection{Development of an indicator system for sustainable development of Jining City}

A set of indicators should be flexible enough to respond to the different needs of urban management and trends of urban development at the different levels and scales of the urban system. They should not only describe a present condition, but also integrate the dynamics of the whole system (Allen, 2001; Repetti and Desthieux, 2006). Based on the preceding criteria, the indicators of City Construction issued by State Environmental Protection Administration of China (SEPA), and the present situations of Jining City and Shandong Province, the authors designed an indicator system for Jining City that comprised 52 indicators in four themes: economic growth and efficiency, ecological and infrastructural construction, environmental protection, social and welfare progress. These indicators and their values in 2004, 2007, 2010, and 2020, are shown in Table 1. The data of 2004 is the status value (Jining Municipal Statistical Bureau, 2005), while the data of 2007, 2010 and 2020 are the planned values coming from the ecological planning of Jining City (2004-2020) finished by our research group (Research Center for Eco-Environmental Sciences, Chinese Academy of Sciences, 2005). Referencing to the target values of indicators from SEPA, according to the relative predicting model, the indicator values in 2007, 2010 and 2020 can be obtained.

One traditional standard approach for such assessments is to interview just a few experts, and obtain consensus on the value of an indicator. Although the use of a large sample reduces subjectivity, it does not completely eliminate subjectivity, and it is not convenient to gather these experts every year to perform a new assessment. Expert assessments fail to meet the criteria in Table 1 for an acceptable indicator system. These indicators proposed in the paper solve this problem.

\subsection{Development of a Full Permutation Polygon Synthetic Indicator (FPPSI) method}

In the FPPSI method, an $n$-sided polygon is created to represent the theoretical maximum values of each of $n$ indicators, with the radius at each vertex (i.e., the distance from the center of the polygon) defined by the upper limits of the standardized value for each indicator. Thus, there are aggregately $(n-1) ! / 2 n$-sided polygons. The synthetic indicator is defined as the mean of the ratios of the area of any $n$-sided polygon to the area of the polygon defined using a normalized value of 1.0 for each indicator.

The standardization process can be described as follows:

$F(X)=a \frac{X+b}{X+c}, \quad a \neq 0, \quad X \geq 0$ where $F(X)$ meets the following conditions:

$$
\begin{aligned}
& \left.F(X)\right|_{X=L}=-1 \\
& \left.F(X)\right|_{X=T}=0 \\
& \left.F(X)\right|_{X=U}=+1
\end{aligned}
$$

where $U, L$, and $T$ represent the upper limit, the lower limit and the threshold for parameter $X$, respectively. Then

$$
F(x)=\frac{(U-L)(U-T)}{(U+L-2 T) X+U T+L T-2 L U}
$$

The equation can then be standardized:

$$
S_{i}=\frac{\left(U_{i}-L_{i}\right)\left(X_{i}-T_{i}\right)}{\left(U_{i}+L_{i}-2 T_{i}\right) X_{i}+U_{i} T_{i}+L_{i} T_{i}-2 U_{i} L_{i}}
$$

An outer regular $n$-sided polygon can be formed by $n$ indicators, where $n$ vertices represent the instance of $S_{i}=1$; the central point represents $S_{i}=-1$; and the radius from each vertex to the central point represents the value of the corresponding standardized indicator. An inner polygon that lies midway between the outer polygon and the center of the polygon represents the threshold values of the indicators, where $S_{i}=0\left(X_{i}=T\right)$. Inside the inner polygon, the values of the standardized indicators are less than their thresholds and are negative; outside the inner polygon, the values are greater than their threshold values and are positive (Fig. 2).

The number of triangles formed by the lines between the central point and the $n$ indicators (vertices) is calculated as follows:

$\frac{n(n-1)}{2}$

The total area of a polygon can be calculated as follows:

$0.5 \sin \left(\frac{\pi}{n}\right) \sum_{i \neq j}\left(S_{i}+1\right)\left(S_{j}+1\right)$

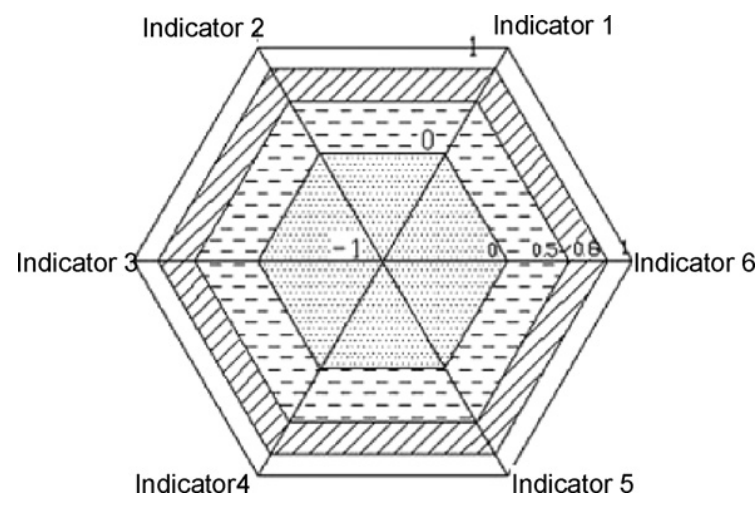

Fig. 2. An example of the Full Permutation Polygon Synthetic Indicator method. 
where $S_{i}$ represents indicator $i$, and $S_{i}+1$ represents the distance from the endpoint of indicator $i$ to the central point. The standardization interval is $[-1,+1]$.

There are $n \times(n-1) ! / 2=n ! / 2$ triangles created from the number of indicators $(n-1) ! / 2$. The sum of their areas is

$$
\left(0.5 \sin \left(\frac{\pi}{n}\right) \sum_{i \neq j}\left(S_{i}+1\right)\left(S_{j}+1\right)\right) \times \frac{n !}{2} \times \frac{2}{n(n-1)}
$$

All of the areas of the $(n-1) ! / 2$ regular outer polygons (with a side length equal to two units) can be calculated as

$0.5 \times 4 \times n \times \frac{(n-1) !}{2}$

The value of FPPSI is then obtained by calculating the following ratio:

$S=\frac{\sum_{i \neq j}^{i, j}\left(S_{i}+1\right)\left(S_{j}+1\right)}{2 n(n-1)}$

where $S$ is the value of the synthetic indicator, which represents the sum of the values for all indicators at a lower level in the hierarchy and can be standardized to account for the immediately higher level in the hierarchy.

Based on relevant data (Wang and $\mathrm{Xu}, 2005$ ), as well as values in national and international standards, the authors established a four-level classification system based on the value of $S$ (Table 2).

\section{Results}

Based on the three planning phases (2007, 2010, and 2020) described in Table 1, the authors evaluated the development of Jining City from four perspectives using the FPPSI method: economic growth, ecological construction, environmental protection, and social progress. The authors then synthesized the results to provide a single comprehensive indicator of sustainability.

\subsection{Economic growth and efficiency}

Based on the 2004 data, the synthetic indicator for economic growth in Jining is low (0.10), and ranks as level IV (bad). The major reasons for this problem are the low per capita GDP, average annual per capita tax revenues, average annual income per farmer, and GDP density. If the planning phases are completed successfully, the indicator for economic growth will increase gradually, to 0.26 (level III) in 2007, 0.51 (level II) in 2010, and 0.80 (level I) in 2020 (Fig. 3). Jining City has an opportunity to develop its potential sustainability by transitioning from a focus on resource exploitation to a more synergetic system focused on resource recycling and reuse, a commercial and service industry, and a cultural and tourist industry.

\subsection{Ecological and infrastructural construction}

Due to the low indicator values for the proportions of ecological and environmental restoration in mineral zones, for the proportion of degraded land undergoing restoration, for the proportion of

Table 2

Classification criterion for urban sustainable development capacity.

\begin{tabular}{lll}
\hline Level & Value of $S$ (the synthetic indicator) & Qualitative evaluation \\
\hline I & $>0.75$ & Excellent \\
II & $0.50-0.75$ & Good \\
III & $0.25-0.50$ & Moderate \\
IV & $<0.25$ & Bad \\
\hline
\end{tabular}

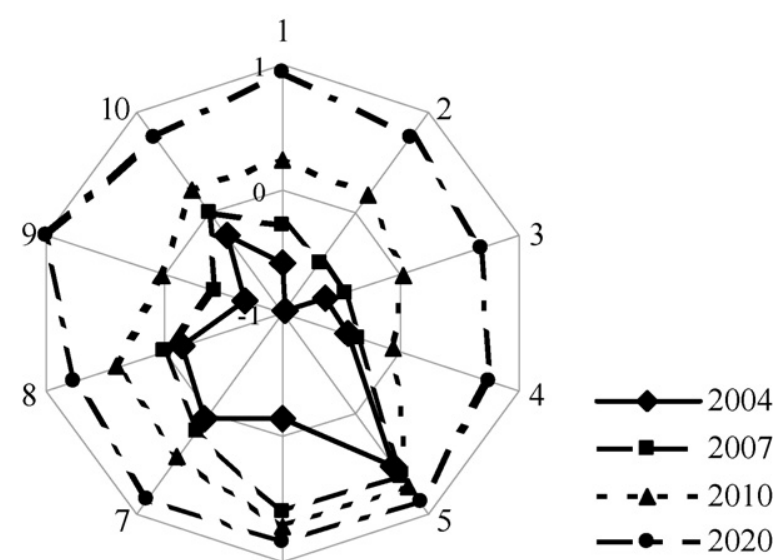

Fig. 3. Comprehensive evaluation of the economic growth and efficiency of Jining City. (1) Per capita GDP, (2) average annual per capita tax revenues, (3) average annual income per farmer, (4) average annual income per urban resident, (5) proportion of GDP generated by the service industry, (6) energy consumption ( $t$ coal equivalent) per 10,000 RMB of GDP, (7) water consumption per 10,000 RMB of GDP, (8) proportion of all companies that have received ISO-14000 certification, (9) GDP per unit area covered by the city and (10) proportion of GDP devoted to environmental investment.

restored mining area, for the proportion of green cover in the builtup urban areas, and for the forest cover, the synthetic indicator for ecological construction in Jining is 0.20 (bad). However, ecological construction will increase gradually as the current plans are implemented, to 0.35 (level III) in 2007, 0.58 (level II) in 2010, and 0.95 (level I) in 2020 (Fig. 4). Currently, the primary barriers to ecological construction in Jining relate to the need to restore areas in mineral zones in which subsidence has occurred, to restore degraded soil, and to increase the percentage of green space and the service functions of this space.

\subsection{Environmental protection}

As in 2004, the indicator for environmental protection in Jining was 0.19 (level IV). The low indicator values for the proportion

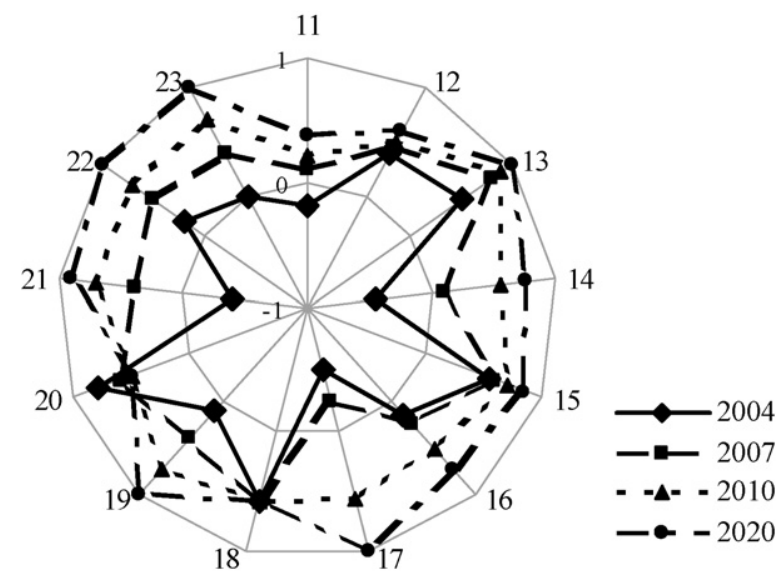

Fig. 4. Comprehensive evaluation of ecological and infrastructural construction in Jining City. (11) Forest cover, (12) proportion of the natural reserves, (13) proportion of degraded land undergoing restoration, (14) per capita area of public urban green space, (15) proportion of infrastructure that qualifies as ecological construction, (16) proportion of green cover in the built-up urban area, (17) the proportion of restored mining area, (18) proportion of the total area covered by wetlands, (19) proportion of eco-counties meeting the standard of SEPA, (20) proportion of impervious land, (21) proportion of rivers with natural bank, (22) proportion of Ecological Impact Assessment done for projects and (23) proportion of people participated in environmental protection activities. 

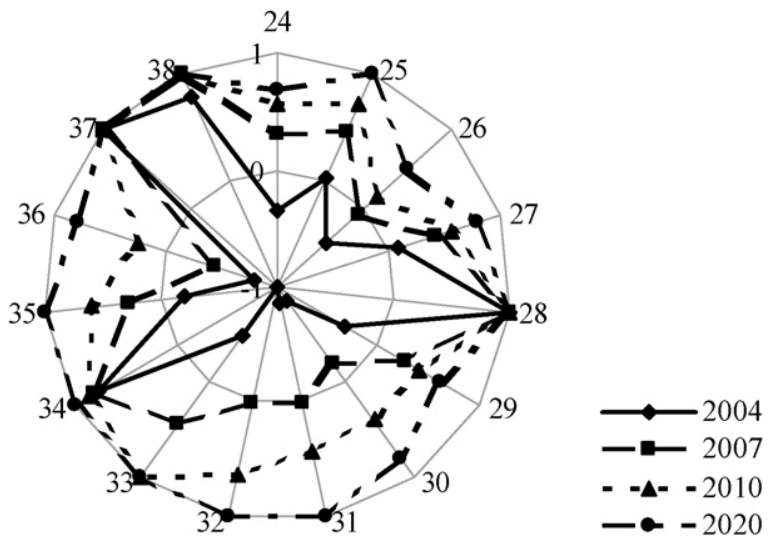

Fig. 5. Comprehensive evaluation of environmental protection in Jining City. (24) number of days when the urban air quality index reaching Class II or better, (25) proportion of water areas in which pollution levels are below the limit specified in the national standards, (26) $\mathrm{SO}_{2}$ discharge per 10,000 RMB of GDP, (27) chemical oxygen demand (COD) discharged into surface water per 10,000 RMB of GDP, (28) proportion of the urban drinking water supply that is safe to drink according to the national standards, (29) proportion of centralized treatment of urban sewage, (30) proportion of industrial water that is recycled, (31) proportion of the rural sewage discharging that meets national pollution standards, (32) proportion of total hours per year in which noise levels are below the level specified in the national standard, (33) proportion of urban domestic wastes that are treated according to national standards, (34) proportion of industrial solid wastes that are treated and reused, (35) proportion of tourists who are satisfied with the environment at tourism sites, (36) use of inorganic fertilizers per unit area (use intensity), (37) proportion of livestock wastes that are treated and (38) proportion of industrial sewage discharging that meets national standards.

of centralized treatment of urban sewage, for the status of rural sewage discharging that meets national standards, for the proportion of industrial water reuse, for the proportion of non-hazardous disposal of urban solid waste, for $\mathrm{SO}_{2}$ emissions, and for urban air quality all contribute to this low value, whereas these problems are mitigated to some extent by an improved utilization of manure in livestock farms, utilization of industrial solid waste, and proportion of industrial waste water treated to national standards. Overall, compared with the progress that will occur in the economic, ecological, and social aspects, Jining will struggle to improve environmental protection. The indicator for environmental protection will increase gradually to 0.48 (level III) in 2007, 0.70 (level II) in 2010, and 0.95 (level I) in 2020 (Fig. 5). To improve the level of environmental protection, planners must emphasize projects to control and prevent water pollution.

\subsection{Social and welfare progress}

As of 2004, the indicator for social progress (0.32, level III) is moderate. The proportion of high school graduates who enter an

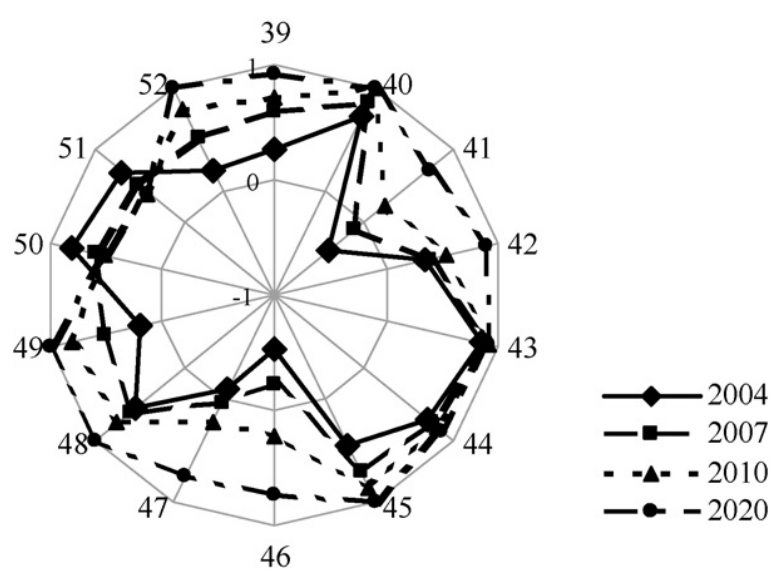

Fig. 6. Comprehensive evaluation of social and welfare progress in Jining City. (39) Proportion of the population residing in urban areas, (40) proportion of homes and businesses that use; natural gas instead of coal, (41) proportion of urban buildings that are centrally heated, (42) Engle's coefficient, proportion of income expended on food (Wang et al., 2006), (43) Gini's coefficient, a number between zero and one that measures the degree of inequality in the distribution of income in a given society (Kimura, 1994), (44) proportion of high school graduates who enter a university or college, (45) proportion of the population that is satisfied with their environment, (46) average number of years of education per citizen, (47) number of people who have graduated from at least technical programs and high school per 10,000 people, (48) average life expectancy, (49) road area per person, (50) average living space per person, (51) water use for living per person and (52) hospital beds per 10,000 population.

university or college, the proportion of urban use of natural gas, and the average life expectancy are all favorable factors, but the number of years of schooling per capita and the number of people who have graduated from at least technical programs and high school per 10,000 people are both low. The indicator for social progress will increase to 0.48 (level III) in 2007, 0.64 (level II) in 2010, and 0.88 (level I) in 2020 (Fig. 6). In the future, Jining plans to increase the average number of years of schooling to improve overall educational levels. An increased number of professional workers from technical schools or from the field of ecological construction will also help to address social issues related to aging and of public participation in environmental protection (since citizens educated about the importance of the environment are more likely to understand the need to participate in protecting the environment).

\subsection{Comprehensive evaluation of urban sustainable development in Jining}

As in 2004, the comprehensive indicator for urban sustainable development in Jining is 0.24 (level IV), which represents a poor status. Guided by the urban development plan described in Table 1, the comprehensive indicator will reach a value of 0.45 (level III) in

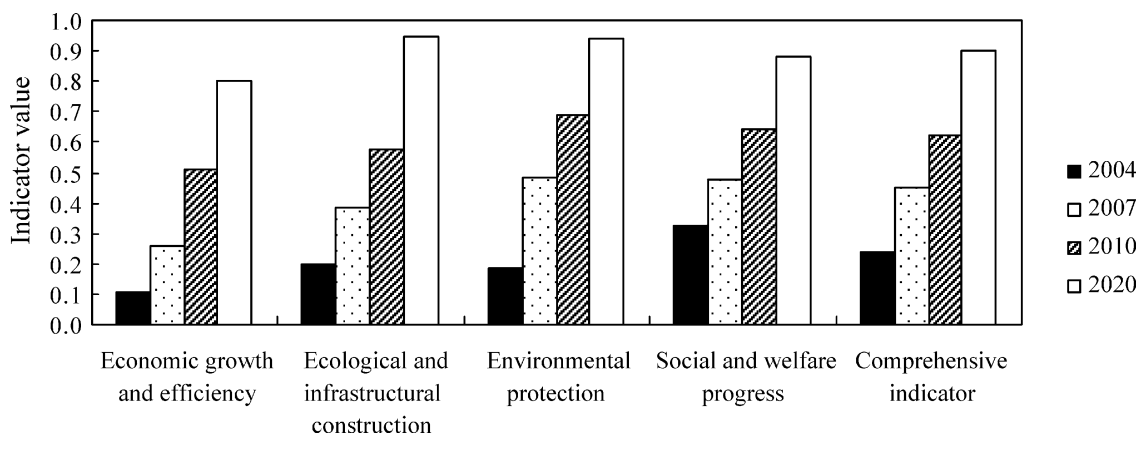

Fig. 7. Comprehensive evaluation of urban sustainable development in Jining City. 
2007, 0.62 (level II) in 2010, and 0.90 (level I) in 2020, demonstrating the potential to upgrade the urban capacity for sustainability (Fig. 7). However, even in 2020, a gap of $16 \%$ will remain between the planned target and the ideal value of the indicators (i.e., a value of 1.0 ), suggesting that planners must take steps to continue improving the values of many of the indicators even after the planning period ends in 2020.

\section{Discussion}

The FPPSI method described in this paper provides a suite of individual indicators that can be combined synergetically into a series of comprehensive hierarchical indicators; in the present study, then authors chose 52 individual third-level indicators that can be grouped into four second-level indicators (economic growth and efficiency, ecological and infrastructural construction, environmental protection, social and welfare progress), which can in turn be combined into a single first-level comprehensive indicator. The approach provides both a geometrically intuitive visualization of the status of each indicator (as shown in Figs. 3-6), but also precise algebraic values. In addition, it provides both static indicators and the ability to portray dynamic temporal trends. Compared with traditional simple weighted methods (Huang et al., 1998; Button, 2002; Holden, 2006). The FPPSI method only requires analysts to set upper and lower limits and critical values (by referring to correlative thresholds) rather than employing subjective expert judgments on the values of coefficients, and should thus reduce the level of bias that can distort subjective assessments. This method is objective, quantitative and superior. The traditional expert opinion method fails to meet these criteria. An additional advantage of the FPPSI approach is that progress towards a goal can be quantified by measuring the indicators. In expert-based approaches, judgments of progress can also be highly subjective. Although the choice of indicators is somewhat subjective, the FPPSI method at least allows planners to choose quantifiable metrics that relate to management goal. The FPPSI method alters the traditional additive approach to combining indicators by using a multi-dimensional approach that better reflects the integrative system principle that the whole is more than the sum of its parts. The authors have discussed the indicator system that developed to assess sustainable development of Jining, and the values of the indicators at different phases of the urban development plan from 2007 to 2020, with local governments and other relevant agencies and have communicated their importance for improving the sustainability of Jining City. The results of our analysis should thus support decisions made to promote sustainable development of the city, and should permit tracking of the results of these decisions.

The limited factors in this case study are mainly land restoration, polluted water control, and industry transformation. Different strategies should be adopted due to different limited factors. Ecological restoration and engineering measures should be adopted to the deserted mines to restore their environmental condition and green space. In addition, efforts should be made to restore the damaged rivers, canals, lakes and wetlands according to different conditions. Strictly strengthen management and supervision on living and industrial pollution. Control polluting sources and improve the operation of pollution treatment facilities and ensure industrial pollution discharging up to national standard. Speed up the scheme of activating water in urban area. Increase the introduction of fresh water and strengthen the self-purification of urban water bodies. Speed up industrial transformation according to ISO-14000 requirements and promote clean production and circular economy. The dominated industry suggested in Jining City is ecosystem restoration industry, eco-tourism, cultural, leisure and service industry.
Urban sustainable development is a long-term arduous task that aims to develop a stronger synthesis of social, economic, and environmental factors. By choosing indicators which values can be influenced by managers and urban planners, practical measures can be taken to implement improvements to the indicators. Increasing the capacity for urban sustainable development requires managers and planners to promote sustainable use of the ecosystem at both the urban and the regional level, and requires the adaptation of current processes so that they place less of a burden on ecosystem services. It has been widely acknowledged that promoting a transition to sustainability requires certain changes: from a traditional economy based on production and the exploitation of natural resources to a service economy based on recycling, reuse, and knowledge; from lifestyles based on consuming to lifestyles based on conserving, behaving in an environment-friendly manner, and using resources efficiently; the development of systems that are socially and environmentally harmonious; and the development of ecologically efficient industries. All of these steps will be necessary to develop a new generation of citizens capable of promoting economically, socially, and ecologically urban sustainable development.

\section{Acknowledgments}

This research was financially supported by, the Knowledge Innovation Project of the Chinese Academy of Sciences (KZCX2-YW-324, KZCX2-YW-422) and the National Natural Science Foundation of China (70803050,70433001). We are grateful to the Jining Environmental Protection Bureau for providing information on their urban planning and development initiatives. Finally, we thank Dr. Geoff Hart for his constructive suggestions for correcting and polishing the manuscript.

\section{References}

Allen, E., 2001. INDEX: software for community indicators. In: Brail, R.K., Klosterman, R.E. (Eds.), Planning Support Systems. ESRI Press, Redlands, pp. 229-261.

Attwell, K., 2000. Urban land resource and urban planting-case studies from Denmark. Landscape Urban Plan. 52, 145-163.

Bolund, P., Hunhammar, S., 1999. Ecosystem services in urban areas. Ecol. Econ. 29, 293-301.

Button, K., 2002. City management and urban environmental indicators. Ecol. Econ. 40, 217-233.

Cheng, J.Q., Turkstra, J., Peng, M.J., Du, N.R., Ho, P., 2006. Urban land administration and planning in China: opportunities and constraints of spatial data models. Land Use Policy 23, 604-616.

Costanza, R., d'Arge, R., de Groot, R., Farber, S., Grasso, M., Hannon, B., Laskin, R., Sutton, P., van den Belt, M., 1997. The value of the world's ecosystem services and natural capital. Nature 387 (15), 253-260.

de Groot, R., 2006. Function-analysis and valuation as a tool to assess land use conflicts in planning for sustainable, multi-functional landscapes. Landscape Urban Plan. 75, 175-186.

Diamantini, C., Zanon, B., 2000. Planning the urban sustainable development: the case of the plan for the province of Trento, Italy. Environ. Impact Asses. 20, 299-310.

Fang, S., Gertner, G.Z., Sun, Z., Anderson, A.A., 2005. The impact of interactions in spatial simulation of the dynamics of urban sprawl. Landscape Urban Plan. 73, 294-306.

Haughton, G., 1997. Developing sustainable urban development models. Cities 14 (4), 189-195.

Herzele, A.V., Wiedemann, T., 2003. A monitoring tool for the provision of accessible and attractive urban green spaces. Landscape Urban Plan. 63, 109-126.

Holden, M., 2006. Urban indicators and the integrative ideals of cities. Cities 23 (3), 170-183.

Huang, S.L., Wong, J.H., Chen, T.C., 1998. A framework of indicator system for measuring Taipei's urban sustainability. Landscape Urban Plan. 42, 15-27.

Jenny, A., Ericson, A., 2006. A participatory approach to conservation in the Calakmul Biosphere Reserve, Campeche, Mexico. Landscape Urban Plan. 74, 242-266.

Jining Municipal Statistical Bureau, 2005. Jining Statistical Yearbook. Jining Municipal Statistical Bureau, Jining, China, pp. 1-30 (in Chinese).

Kimura, K., 1994. A micro-macro linkage in the measurement of inequality: another look at the Gini coefficient. Qual. Quant. 28, 83-97.

Landelma, R., Salminen, P., Hokkanen, J., 2000. Using multicriteria methods in environmental planning and management. Environ. Manage. 26 (6), 595-605. 
Li, F., Wang, R.S., Liu, X.S., Zhang, X.L., 2005a. Urban forest in China: development patterns, influencing factors and research prospects. Int. J. Sust. Dev. World Ecol. 12, 197-204.

Li, F., Wang, R.S., Paulussen, J., Liu, X.S., 2005b. Comprehensive concept planning of urban greening based on ecological principles: a case study in Beijing, China. Landscape Urban Plan. 72, 325-336.

Ma, S.J., Wang, R.S., 1984. Social-economic-natural complex ecosystem. Acta Ecol. Sin. 4 (1), 1-9 (in Chinese).

Malkina-Pykh, I.G., 2002. Integrated assessment models and response function models: pros and cons for sustainable development indices design. Ecol. Indic. 2, 93-108.

Merkle, A., Kaupenjohann, M., 2000. Derivation of ecosystemic effect indicatorsmethod. Ecol. Model. 130, 39-46.

Nader, M.R., Salloum, B.A., Karam, N., 2008. Environment and sustainable development indicators in Lebanon: a practical municipal level approach. Ecol. Indic. 8 , 771-777.

OECD, 1997. Better Understanding Our Cities: The Role of Urban Indicators. OECD Publication, Paris.

Pauleit, S., Duhme, F., 2000. Assessing the environmental performance of land cover types for urban planning. Landscape Urban Plan. 52, 1-20.

Pauleit, S., Ennos, R., Golding, Y., 2005. Modeling the environmental impacts of urban land use and land cover change-a study in Merseyside, UK. Landscape Urban Plan. 71, 295-310.

Repetti, A., Desthieux, G., 2006. A relational indicator set model for urban land-use planning and management: methodological approach and application in two case studies. Landscape Urban Plan. 77, 196-215.

Research Center for Eco-Environmental Sciences, Chinese Academy of Sciences, 2005. The ecological planning of Jining City (2004-2020), pp. 19-21 (in Chinese).

Riley, J., 2001. Indicator quality for assessment of impact of multidisciplinary systems. Agr. Ecosyst. Environ. 87, 121-128.

Savard, J.-P.L., Clergeau, P., Mennechez, G., 2000. Biodiversity concepts and urban ecosystem. Landscape Urban Plan. 48, 131-142.

Schell, L.M., Ulijaszek, S.J., 1999. Urbanism, Health and Human Biology in Industrialized Countries. Cambridge University Press, London, pp. 59-60.
Shearer, A.W., Mouat, D.A., Bassett, S.D., Binford, M.W., Johnson, C.W., Saarinen, J.A 2006. Examining development-related uncertainties for environmental management: strategic planning scenarios in Southern California. Landscape Urban Plan. 77, 359-381.

Spangenberg, J.H., Pfahl, S., Deller, K., 2002. Towards indicators for institutional sustainability: lessons from an analysis of Agenda 21. Ecol. Indic. 2 61-77.

Wang, H., Du, S., Zhai, F., Popkin, B.M., 2006. Trends in the distribution of body mass index among Chinese adults, aged 20-45 years (1989-2000). Int. J. Obesity $1-7$.

Wang, R.S., Wang, X.R., Hu, D., Tang, L.J., 2004. Eco-services of Urban Survival and Development. China Meteorological Press, Beijing, pp. 50-60 (in Chinese).

Wang, R.S., Xu, H.X., 2005. A Comprehensive Approach for Yangzhou Eco-city Development. China Science and Technology Press, Beijing, pp. 3-20 (in Chinese).

Zhang, K.M., Wen, Z.G., Du, B., Song, G.J., 2003. Assessment on Eco-city and Indicator System. China Chemical Industry Press, Beijing, pp. 1-50 (in Chinese).

Zhang, Y., Yang, Z.F., Yu, X.Y., 2006. Measurement and evaluation of interactions in complex urban ecosystem. Ecol. Model. 196, 77-89.

Feng Li is currently an associate professor of State Key Laboratory of Urban and regional Ecology, Research Center for Eco-Environmental Sciences, Chinese Academy of Sciences. He holds a BS in forestry from Inner Mongolia Agriculture in 1996, a MS in urban forestry from Chinese Academy of Forestry in 2001 and a Ph.D. in urban ecology from Chinese Academy of Sciences in 2004. His research and publications focus on urban and industry ecology, urban ecological planning and management, eco-services of social-economic-natural complex ecosystem. He has done many works in research of urban ecosystem services and management for National Natural Science Foundation of China (Nos. 70803050, 39930040 70433001 ) and several urban and regional ecological planning projects, such as Beijing, Guangzhou, Yangzhou, Jining, Dafeng, Changzhou, Huaibei city and so on. He is secretary-general of Urban Ecology Committee for Ecological Society of China. More than 30 articles about urban ecology have been published in international journals. 